Pacific Journal of Mathematics

MODULES WHOSE QUOTIENTS HAVE FINITE GOLDIE 


\title{
MODULES WHOSE QUOTIENTS HAVE FINITE GOLDIE DIMENSION
}

\author{
V. P. Camillo
}

If $M$ is a module and $M$ is a submodule of $M$, then $N$ is irreducible in $M$ if $N$ cannot be written as a proper intersection of two submodules of $M$. The purpose of this note is to study modules whose submodules can be written as a finite intersection of irreducible submodules. Such modules are characterized by the fact that their quotients all have finite Goldie dimension, so they are called q.f.d. modules.

The main result is: A module $M$ is q.f.d. if and only if every submodule $N$ has a finitely generated submodule $T$ such that $N / T$ has no maximal submodules. Because $T$ is finitely generated this generalizes a theorem of Shock (using his ideas), who showed a q.f.d. module $M$ having the property that every subquotient of $M$ has a maximal submodule must be noetherian (and conversely, of course).

The q.f.d. condition also arises in the study of Krull dimension because a module with Krull dimension must be q.f.d. [1].

First, a remark, which we isolate as a lemma.

Lemma. A module $M$ is q.f.d. if and only if each quotient of $M$ has finite dimensional socle (possible zero).

Proof. Every nonzero module has a quotient with nonzero socle. (Take $A \subset M$ to be maximal with respect to not containing $m, 0 \neq$ $m \in M$.) So an infinite direct sum of modules has a quotient with infinite dimensional socle.

THeOREM. A module $M$ is q.f.d. if and only if every submodule $N$ contains a finitely generated submodule $T$, such that $N / T$ has no maximal submodules.

Proof. Suppose that $X$ is a module such that every finitely generated submodule of $X$ is contained in a maximal submodule of $X$. Having chosen maximal submodules $M_{1}, \cdots, M_{n}$ and elements $x_{1}, \cdots, x_{n}$ such that $x_{i} \notin M_{i}$, but $x_{i} \in M_{j}$ for $j>i$, choose a maximal submodule $M_{n+1}$ containing $x_{1} R+\cdots+x_{n} R$ and an element $x_{n+1}$ not in $M_{n+1}$.

Let $\bar{X}=X / \bigcap_{i=1}^{\infty} M_{i}$. Then, $\bar{X}=\bigcap_{i=1}^{n} M_{i} \oplus \bigcap_{i=n+1}^{\infty} M_{i}$, because, if we denote the right hand summand by $M$, we have a strict descending chain $M \supset M \cap M_{n} \supset M \cap M_{n} \cap M_{n-1} \cdots$ so that $M$ has the same 
composition length as $X / \bigcap_{i=1}^{n} M_{i}$.

Thus, $\bar{X}$ has direct sums of arbitrary size, and so is infinite dimensional.

Conversely, we wish to show that if for every $N \subset M$, we can always find such a $T$, then $M$ has no quotient which contains an infinite direct sum. If $M / K$ does, then by the lemma we can find a $K^{\prime}$ with $M / K^{\prime}$ having an infinite direct snm of simple submodules. Let $K^{\prime} \subset S \subset M$ be such that $S / K^{\prime}$ is this infinite direct sum. Choose $T$ finitely generated such that $S / T$ has no maximal submodules. Then $S / T+K^{\prime}$ has no maximal submodules. But $S / T+K^{\prime}$ is a homomorphic image of the semisimple module $S / K^{\prime}$ so $S / T+K^{\prime}$ is semisimple, and always has maximal submodules if it is not zero. So, it must be zero and $S=T+K^{\prime}$. Since $T$ is finitely generated $S / K^{\prime}$ must be, a clear impossibility.

REMARK. The above naturally raises the question, when are finitely generated modules finite dimensional? We observe the following:

Proposition. If cyclic modules are finite dimensional then finitely generated modules are.

Proof. Let $E(M)$ denote the injective hull of the module $M$. Let $M$ be generated by $\left\{m_{1}, \cdots, m_{r}\right\}$. Let $E(M)=E\left(m_{1} R\right) \oplus K_{1}$, and write $m_{2}=a_{1}+k_{1}$. Then $K_{1}=E\left(k_{1} R\right) \oplus K_{2}$. So $E(M)=E\left(m_{1} R\right) \oplus$ $E\left(k_{1} R\right) \oplus K_{2}$, and $m_{1} R+m_{2} R \subset E\left(m_{1} R\right) \oplus E\left(k_{1} R\right)$. Continue in this fashion to get $E(M)$ as a finite direct sum of injective hulls of cyclic modules. These are finite dimensional, so $M$ is.

Since there are non-noetherian valuation rings (ideals are linearly ordered), there are non-noetherian rings whose finitely generated modules are finite dimensional. The result cited in the first paragraph is 4.10 of [4].

\section{REFERENCES}

1. Robert Gordon and J. C. Robson, Krull Dimension, Amer. Math. Soc. Memoir 133.

2. - The Gabriel dimension of a module, J. Algebra, 29, (1974), 459-573.

3. Robert Shock, Dual generalizations of the Artinian and noetherian conditions. Pacific J. Math., 54 (1974), 227-235.

4. Sharpe and Vamos, Injective Modules, Cambridge University Press, 1972.

Received July 22, 1976.

UNIVERSITY OF IOWA

IowA City, IA 52242 


\section{PACIFIC JOURNAL OF MATHEMATICS}

\section{EDITORS}

RICHARD ARENS (Managing Editor)

University of California

Los Angeles, CA 90024

R. A. BEAUMONT

University of Washington

Seattle, WA 98105

C. C. Moore

University of California

Berkeley, CA 94720

\section{J. DugundJI}

Department of Mathematics

University of Southern California

Los Angeles, CA 90007

R. Finn and J. Milgram

Stanford University

Stanford, CA 94305

\section{ASSOCIATE EDITORS}

\section{E. F. BECKENBACH}

B. H. NEUMANN

F. WoLF

K. YOSHIDA

\section{SUPPORTING INSTITUTIONS}

\author{
UNIVERSITY OF BRITISH COLUMBIA \\ CALIFORNIA INSTITUTE OF TECHNOLOGY \\ UNIVERSITY OF CALIFORNIA \\ MONTANA STATE UNIVERSITY \\ UNIVERSITY OF NEVADA \\ NEW MEXICO STATE UNIVERSITY \\ OREGON STATE UNIVERSITY \\ UNIVERSITY OF OREGON \\ OSAKA UNIVERSITY
}

\author{
UNIVERSITY OF SOUTHERN CALIFORNIA \\ STANFORD UNIVERSITY \\ UNIVERSITY OF HAWAII \\ UNIVERSITY OF TOKYO \\ UNIVERSITY OF UTAH \\ WASHINGTON STATE UNIVERSITY \\ UNIVERSITY OF WASHINGTON \\ AMERICAN MATHEMATICAL SOCIETY
}

The Supporting Institutions listed above contribute to the cost of publication of this Journal, but they are not owners or publishers and have no responsibility for its content or policies.

Mathematical papers intended for publication in the Pacific Jaurnal of Mathematics should be in typed form or offset-reproduced, (not dittoed), double spaced with large margins. Please do not use built up fractions in the text of your manuscript. You may however, use them in the displayed equations. Underline Greek letters in red, German in green, and script in blue. The first paragraph or two must be capable of being used separately as a synopsis of the entire paper. Items of the bibliography should not be cited there unless absolutely necessary, in which case they must be identified by author and Journal, rather than by item number. Manuscripts, in triplicate, may be sent to any one of the editors. Please classify according to the scheme of Math. Reviews, Index to Vol. 39. All other communications should be addressed to the managing editor, or Elaine Barth, University of California, Los Angeles, California, 90024.

The Pacific Journal of Mathematics expects the author's institution to pay page charges, and reserves the right to delay publication for nonpayment of charges in case of financial emergency

100 reprints are provided free for each article, only if page charges have been substantially paid. Additional copies may be obtained at cost in multiples of 50 .

The Pacific Journal of Mathematics is issued monthly as of January 1966. Regular subscription rate: $\$ 7200$ a year (6 Vols., 12 issues). Special rate: $\$ 36.00$ a year to individual members of supporting institutions.

Subscriptions, orders for back numbers, and changes of address should be sent to Pacific Journal of Mathematics, 103 Highland Boulevard, Berkeley, California, 94708.

PUBLISHED BY PACIFIC JOURNAL OF MATHEMATICS, A NON-PROFIT CORPORATION

Printed at Kokusai Bunken Insatsusha (International Academic Printing Co., Ltd.). 8-8, 3-chome, Takadanobaba, Shinjuku-ku, Tokyo 160, Japan.

Copyrit (C) 1975 by Pacific Journal of Mathematics Manufactured and first issued in Japan 


\section{Pacific Journal of Mathematics \\ Vol. 69, No. $2 \quad$ June, 1977}

Carol Alf and Thomas Alfonso O'Connor, Unimodality of the Lévy spectral

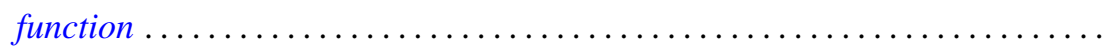

S. J. Bernau and Howard E. Lacey, Bicontractive projections and reordering of

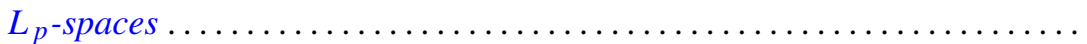

Andrew J. Berner, Products of compact spaces with bi-k and related spaces..... 303

Stephen Richard Bernfeld, The extendability and uniqueness of solutions of ordinary differential equations ...............................

Marilyn Breen, Decompositions for nonclosed planar m-convex sets ..........

Robert F. Brown, Cohomology of homomorphisms of Lie algebras and Lie

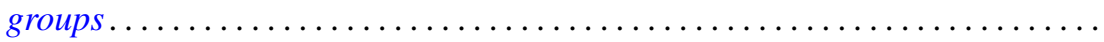

Jack Douglas Bryant and Thomas Francis McCabe, A note on Edelstein's iterative test and spaces of continuous functions ....................

Victor P. Camillo, Modules whose quotients have finite Goldie dimension ....... 333

David Downing and William A. Kirk, A generalization of Caristi's theorem with

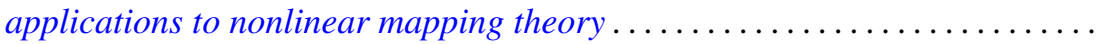

Daniel Reuven Farkas and Robert L. Snider, Noetherian fixed rings ...........

Alessandro Figà-Talamanca, Positive definite functions which vanish at

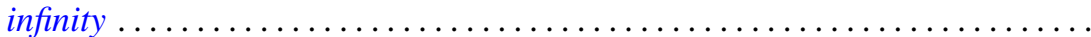

Josip Globevnik, The range of analytic extensions .................. 365

André Goldman, Mesures cylindriques, mesures vectorielles et questions de

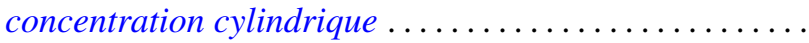

Richard Grassl, Multisectioned partitions of integers..........

Haruo Kitahara and Shinsuke Yorozu, A formula for the normal part of the

Laplace-Beltrami operator on the foliated manifold .... .

Marvin J. Kohn, Summability $R_{r}$ for double series .........

Charles Philip Lanski, Lie ideals and derivations in rings with involution ..

Solomon Leader, A topological characterization of Banach contractions . .

Daniel Francis Xavier O’Reilly, Cobordism classes of fiber bundles . .

James William Pendergrass, The Schur subgroup of the Brauer group . .

Howard Lewis Penn, Inner-outer factorization of functions whose Fourier series

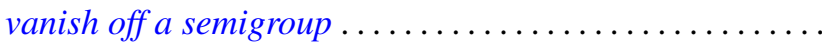

501

William T. Reid, Some results on the Floquet theory for disconjugate definite

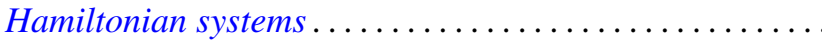

Caroll Vernon Riecke, Complementation in the lattice of convergence

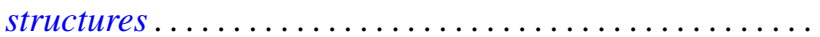

Louis Halle Rowen, Classes of rings torsion-free over their centers ......... 527

Manda Butchi Suryanarayana, A Sobolev space and a Darboux problem ....... 535

Charles Thomas Tucker, II, Riesz homomorphisms and positive linear maps.... 551

William W. Williams, Semigroups with identity on Peano continua ........... 557

Yukinobu Yajima, On spaces which have a closure-preserving cover by finite 